\title{
Prevalence, antimicrobial resistance, and genotyping of Shiga toxin-producing Escherichia coli in foods of cattle origin, diarrheic cattle, and diarrheic humans in Egypt
}

\author{
Walid Elmonir ${ }^{\text {* }}$, Samar Shalaan ${ }^{1}$, Amin Tahoun², Samy F. Mahmoud ${ }^{3,4}$, Etab M. Abo Remela ${ }^{5,6}$, Radwa Eissa ${ }^{7}$, \\ Hanem El-Sharkawy ${ }^{8}$, Mustafa Shukry ${ }^{9}$ and Rasha N. Zahran ${ }^{10}$
}

\begin{abstract}
Shiga toxin-producing Escherichia coli (STEC) is a pathotype of E. coli that causes enteric and systemic diseases ranging from diarrhoea to severe hemorrhagic colitis (HC) and hemolytic uremic syndrome (HUS). The emergence of multidrug-resistant (MDR) STEC from cattle sources has increased public health risk and limited treatment options. The prevalence of STEC was investigated in 200 raw food samples (milk and beef samples) and 200 diarrheic samples (cattle and human samples) in a matched region. The presence of stx genes (stx 1 and stx2), carbapenemase-encoding genes ( $b / a_{\mathrm{VIM}}, b / a_{\mathrm{NDM}-1}$, and $\left.b / a_{\mathrm{IMP}}\right)$, and extended-spectrum $\beta$-lactamase (ESBL)-encoding genes (bla $a_{\mathrm{TEM}}$ group, bla $a_{\mathrm{CTX}}$ M1 group, and bla $a_{\text {OXA-1 }}$ group) was screened by polymerase chain reaction (PCR). Antibiogram and Enterobacterial repetitive intergenic consensus (ERIC)-PCR were also conducted. STEC isolates were identified in $6.5 \%(13 / 200)$ of food samples [6\% (6/100) of milk and 7\% (7/100) of beef samples] and in 11\% (22/200) of diarrheic cases [12\% (12/100) of cattle and 10\% (10/100) of human samples]. We found that $\mathrm{O} 26(4.5 \%, 18 / 400)$ and $\mathrm{O} 111(1.5 \%, 6 / 400)$ were the most prevalent STEC serovars and were found more commonly in diarrheic samples. STEC strains with both stx genes, stx 2 only, and stx 1 only genotypes were present in $62.9 \%$ (22/35), 20\% (7/35), and 17.1\% (6/35) of isolates, respectively. Carbapenemase-producing STEC (CP STEC) isolates were found in $1.8 \%(7 / 400)$ of samples $[0.5 \%(1 / 200)$ of foods and $3 \%(6 / 200)$ of diarrheic cases]. The bla VIM gene was detected in all CP STEC isolates, and one human isolate carried the bla $a_{\text {NDM-1 }}$ gene. ESBL-producing STEC strains were detected in 4.3\% (17/400) of samples [1.5\% (3/200) of food samples and $7 \%$ (14/200) of diarrheic cases]. The bla $a_{\mathrm{TEM}}, b / a_{\mathrm{CTX}-\mathrm{M} 1}$, and bla $a_{\mathrm{OXA}-1}$ genes were detected in $42.9 \%$ (15/35), 28.6\% (10/35), and 2.9\% (1/35) of STEC isolates, respectively. Approximately half $(51.4 \%, 18 / 35)$ of STEC isolates were MDR STEC; all CP STEC and ESBL-producing STEC were also MDR STEC. The highest antimicrobial resistance rates were found against nalidixic acid (51.4\%) and ampicillin (48.6\%), whereas the lowest rates were reported against gentamicin (5.7\%) and ciprofloxacin (11.4\%). MDR STEC strains were 5.3 times more likely to be found in diarrheic cases than in foods ( $P=0.009,95 \% \mathrm{Cl} 1.5-18.7)$. ERIC-PCR was used for genotyping STEC isolates into 27 different ERIC-types (ETs) with a discrimination index of 0.979. Five ETs showed clusters of 2-4 identical isolates that shared the same virulence and antibiotic resistance genetic profile. Human isolates matched food isolates in two of these ET clusters (the O26 CP STEC cluster and the O111 STEC cluster), highlighting the potential cross-species zoonotic transmission
\end{abstract}

*Correspondence: walid.elmonir@gmail.com

${ }^{1}$ Department of Hygiene and Preventive Medicine (Zoonoses), Faculty

of Veterinary Medicine, Kafrelsheikh University, Kafrelsheikh, Egypt

Full list of author information is available at the end of the article

(C) The Author(s) 2021. This article is licensed under a Creative Commons Attribution 4.0 International License, which permits use, sharing, adaptation, distribution and reproduction in any medium or format, as long as you give appropriate credit to the original author(s) and the source, provide a link to the Creative Commons licence, and indicate if changes were made. The images or other third party material in this article are included in the article's Creative Commons licence, unless indicated otherwise in a credit line to the material. If material is not included in the article's Creative Commons licence and your intended use is not permitted by statutory regulation or exceeds the permitted use, you will need to obtain permission directly from the copyright holder. To view a copy of this licence, visit http://creativeco mmons.org/licenses/by/4.0/. The Creative Commons Public Domain Dedication waiver (http://creativecommons.org/publicdomain/ zero/1.0/) applies to the data made available in this article, unless otherwise stated in a credit line to the data. 
of these pathogens and/or their genes in the study region. This is the first detection of CP STEC in milk and diarrheic cattle in Egypt.

Keywords: Shiga toxin-producing Escherichia coli, Carbapenemase genes, Extended-spectrum $\beta$-lactamase genes, Multidrug-resistant, Cattle, Public health risk

\section{Introduction}

Shiga toxin-producing Escherichia coli (STEC) strains are among the most important causes of foodborne illness worldwide [1]. Human infection with these pathogens may result in clinical illness ranging from self-limiting diarrhoea to life-threatening hemolytic uremic syndrome (HUS) [2]. Cattle are attributed to most zoonotic human STEC cases worldwide [1-3]. These animals are the main reservoir of O157 STEC and some important non-O157 STEC such as O26, O111, O113, and O103 [1-4]. E. coli O157:H7 is the predominant STEC serotype associated with human disease and the leading cause of HUS [1, 3]. However, O26, O111, and O103 are also involved in severe human diseases occurring worldwide $[1,3,5,6]$. Most STEC serotypes cause no illness in cattle; however, some serotypes, including O157, O26, O5, and O113, cause diarrhoea, particularly in young calves [7]. Cattle may transmit STEC infections to humans through the consumption of raw or inadequately cooked beef (or products), raw or poorly pasteurized milk (or products), vegetables contaminated by their feces, and via direct occupational contact with live carrier animals or their raw products $[1,2,8]$.

Antimicrobial-resistant pathogens are one of the most threatening public health problems and are predicted to cause the death of 10 million people annually by 2050 [9]. STEC isolates that carry extended-spectrum $\beta$-lactamase (ESBL)-producing genes were reported in humans and cattle sources worldwide [10-13]. These ESBL-producing genes confer resistance to a wide range of $\beta$-lactams, which are the most commonly used antibiotics in clinical and veterinary practices. Additionally, carbapenemase reports (Metallo- $\beta$-lactamase)-producing clinical $E$. coli isolates in humans are increasing worldwide [14, 15]. This is a more pressing public health concern since carbapenemases, which hydrolyze carbapenems, have been used as a last resort against multidrug-resistant (MDR) pathogens. This is critical for STEC because meropenem (MEM, a carbapenem) is recommended to treat early-stage STEC human infections to prevent HUS and subsequent kidney damage [9]. The emergence of carbapenemase-producing STEC (CP STEC) indicates that these isolates could progress to life-threatening diseases with limited treatment options. Carbapenems are not used in veterinary practices; however, recent reports have identified carbapenemase-carrying E. coli in clinical cattle cases [16, 17]. This emergence of CR in cattle isolates may be attributed to either natural selection in the environment or to a human source through the crossspecies transmission of these pathogens or their genetic determinants $[14,17]$. The potential zoonotic transmission of these pathogens warrants monitoring for CP-E. coli in the cattle food chain and other clinical sources. Egypt is part of the Middle East, and this region has the highest annual incidence rates of human STEC cases $\left(152.6 / 10^{5}\right.$ people/year; 160 HUS cases) compared with other areas worldwide [8].

Furthermore, STEC isolates were recovered from cattle sources, including clinical cases and foods in Egypt $[13,18]$. Some of these isolates showed a variable degree of antibiotic resistance; however, there are no data on CP STEC isolates obtained from cattle sources. Therefore, this study aimed to (1) investigate the occurrence of $\beta$-lactam-resistant (including carbapenems) STEC in raw foods of cattle origin (raw beef and milk), diarrheic cattle cases, and diarrheic human cases sharing the same geographical region in Egypt; (2) detect the molecular determinants of their resistance; and (3) define the genetic relatedness or diversity of the isolates for evidence of potential inter- and cross-species (zoonotic) transmission in the study region.

\section{Materials and methods \\ Sampling}

Samples were collected from various foods, diarrheic cattle, and diarrheic humans in several Kafrelsheikh governorate districts in the mid-Delta region of Egypt during the period between March and August 2016. A total of 400 samples were collected, including (1) 200 food samples (100 raw beef and 100 raw milk samples) collected from retail markets; approximately $250-500$ (mL or g) were purchased of each food sample; (2) rectal swab samples collected from 100 diarrheic cattle cases (two swabs per case) admitted to private veterinary clinics in different regions of the Kafrelsheikh governorate; and (3) swab samples collected from the fresh stool of 100 diarrheic humans (two swabs per case) admitted to the Kafrelsheikh general hospital and six private laboratories in different districts. Diarrheic cases were defined as those with more than three loose stools or feces within $24 \mathrm{~h}$. All swab samples were collected from diarrheic cases (humans or cattle) before initiating antibiotic therapy. 
The samples were shipped while chilled in an icebox to the laboratory for further analysis.

\section{Escherichia coli isolation}

After arriving to the lab, the collected samples were enriched in Tryptone Soy broth (TSB; Oxoid, Hampshire, $\mathrm{UK}$ ) and TSB with $20 \mathrm{mg} / \mathrm{L}$ Novobiocin (mTSB for O157; Oxoid, Hampshire, UK). The rectal/stool swabs were enriched in $10 \mathrm{ml}$ of TSB/mTSB broth. The meat samples were homogenized in TSB/mTSB broth $(25 \mathrm{~g} / 225 \mathrm{~mL}$ broth) for $2 \mathrm{~min}$ at $230 \mathrm{rpm}$ using a Stomacher ${ }^{\circledR} 400$ Circulator (Seward, Worthing, UK). Twenty-five milliliters of each milk sample was enriched in $225 \mathrm{ml}$ of TSB/ mTSB broth. The inoculated broths of all samples were incubated at $37^{\circ} \mathrm{C}$ for $6-18 \mathrm{~h}$. Loopfuls from the enrichment tubes were spread on MacConkey agar, Eosin Methylene Blue (EMB agar), and Sorbitol MacConkey agar with Cefixime-Tellurite supplement (CT-SMAC for O157). All media were supplied by Oxoid (Hampshire, UK). The inoculated plates were incubated at $37{ }^{\circ} \mathrm{C}$ for 18-24 h. Suspected E. coli colonies were confirmed biochemically using API-20E (bioMérieux, Marcy-l'Etoile, France).

\section{Molecular identification and serotyping of STEC isolates}

The STEC isolates were identified by the molecular detection of the stx 1 and stx 2 genes, as described before [19]. In brief, bacterial DNA was extracted from the overnight incubated TSB culture using a QIAamp DNA Mini Kit
(Qiagen, Hilden, Germany) according to the manufacturer's instructions. Duplex PCR was conducted to detect the $s t x 1$ and stx 2 genes [20] using a mixture consisting of $25 \mu \mathrm{L}$ of EmeraldAmp MAX PCR master mix (Takara Bio, Kusatsu, Japan), one $\mu \mathrm{L}$ (20 pmol) of each primer, five $\mu \mathrm{L}$ of DNA template $(\sim 100 \mathrm{ng})$, and water to reach a final reaction volume of $50 \mu \mathrm{L}$. The PCR cycling started with an initial denaturation at $94{ }^{\circ} \mathrm{C}$ for $7 \mathrm{~min} ; 35$ cycles of $94{ }^{\circ} \mathrm{C}$ for $1 \mathrm{~min}, 60^{\circ} \mathrm{C}$ for $1 \mathrm{~min}$, and $72{ }^{\circ} \mathrm{C}$ for $2 \mathrm{~min}$; and a final extension at $72{ }^{\circ} \mathrm{C}$ for $10 \mathrm{~min}$. The primer sequences (Metabion, Steinkirchen, Germany) are shown in Table 1. The E. coli O157:H7 Sakai (positive for the stx1 and stx2 genes) and E. coli ATCC 25922 (negative for the $s t x$ genes) reference strains were used controls. The PCR reaction was run by the Applied Biosystem 2720 thermal cycler (Applied Biosystem, Foster City, CA, USA). The PCR products were electrophoresed in $1.5 \%$ agarose gel containing $0.5 \mu \mathrm{g} / \mathrm{ml}$ ethidium bromide. The gel was visualized using AlphaImager ${ }^{\text {TM }}$ Gel Imaging System (Alpha Innotech, San Leandro, CA, USA).

According to the manufacturer's instructions, confirmed STEC isolates were serotyped using diagnostic E. coli $\mathrm{O}$ - and $\mathrm{H}$-antisera sets (Denka Seiken Co., Tokyo, Japan).

\section{Molecular detection of $\beta$-lactamase-encoding genes}

Metallo- $\beta$-lactamase (carbapenemase)-producing genes were detected using a uniplex PCR reaction for the genes $b l a_{\mathrm{VIM}}$ [21], bla $a_{\mathrm{IMP}}$ [22], and $b l a_{\mathrm{NDM}-1}$ [23]. The

Table 1 Primers used in this study and their annealing temperature

\begin{tabular}{|c|c|c|c|c|c|}
\hline Category & Target gene & Primers sequences $\left(5^{\prime}-3^{\prime}\right)$ & PCR type & $\begin{array}{l}\text { Amplified segment } \\
\text { (bp) }\end{array}$ & $\begin{array}{l}\text { Annealing } \\
\text { temperature } \\
\left({ }^{\circ} \mathrm{C}\right)\end{array}$ \\
\hline \multirow[t]{4}{*}{ Stx } & stx 1 & F: ACACTGGATGATCTCAGTGG & Duplex & 614 & 60 \\
\hline & & R: CTGAATCCCCCTCCATTATG & & & \\
\hline & stx2 & F: CCATGACAACGGACAGCAGTT & & 779 & \\
\hline & & R: CCTGTCAACTGAGCAGCACTTTG & & & \\
\hline \multirow[t]{6}{*}{ MBLs } & $b / a_{1 \mathrm{MP}}$ & F: CATGGTTTGGTGGTTCTTGT & Uniplex & 488 & 55 \\
\hline & & R: ATAATTTGGCGGACTTTGGC & & & \\
\hline & $b / a_{\mathrm{VIM}}$ & F: AGTGGTGAGTATCCGACAG & & 261 & 52 \\
\hline & & R: ATGAAAGTGCGTGGAGAC & & & \\
\hline & $b / a_{\mathrm{NDM}-1}$ & F: GGCGGAATGGCTCATCACGA & & 287 & 58 \\
\hline & & R: CGCAACACAGCCTGACTTC & & & \\
\hline \multirow[t]{6}{*}{ ESBLS } & $b l a_{\mathrm{OXA}-1}$ group & F: GGCACCAGATTCAACTTTCAAG & Multiplex & 564 & 61 \\
\hline & & R: GACCCCAAGTTTCCTGTAAGTG & & & \\
\hline & $b l a_{\text {TEM }}$ group & F: CATTTCCGTGTCGCCCTTATTC & & 800 & \\
\hline & & R: CGTTCATCCATAGTTGCCTGAC & & & \\
\hline & $b l a_{C T X-M-1}$ group & F:TTAGGAAGTGTGCCGCTGTA & & 655 & \\
\hline & & R: CGGTTTTATCCCCCACAAC & & & \\
\hline
\end{tabular}


mixture for each PCR reaction $(25 \mu \mathrm{L})$ contained 12.5 $\mu \mathrm{L}$ of EmeraldAmp Max PCR Master Mix, $1 \mu \mathrm{L}$ of each primer $(20 \mathrm{pmol}), 5 \mu \mathrm{L}$ of DNA template, and $5.5 \mu \mathrm{L}$ of water. The following positive control strains were used: E. coli NCTC 13476 (positive for $b l a_{\mathrm{IMP}}$ ), E. coli ATCC BAA-2469 (positive for $b l a_{\mathrm{NDM}-1}$ ), and $K$. pneumoniae NCTC 13439 (positive for $b l a_{\mathrm{VIM}-1}$ ). Additionally, the isolates were screened for ESBL-encoding genes: the $b l a_{\mathrm{TEM}}$ group gene (encodes for TEM; class A $\beta$-lactamases), the $b l a_{\mathrm{CTX}-\mathrm{M}-1}$ group gene (encodes for CTX-M; class A $\beta$-lactamases), and the $b l a_{\text {OXA-1 }}$ group gene (encodes for OXA; class D $\beta$-Lactamases). A multiplex PCR was utilized according to [24]. The reaction mixture was similar to that used to detect $s t x$ genes except for the primers (listed in Table 1). The following PCR cycling conditions were used for all reactions: one cycle at $94{ }^{\circ} \mathrm{C}$ for $7 \mathrm{~min}$; 35 cycles of $95{ }^{\circ} \mathrm{C}$ for $30 \mathrm{~s}$, annealing temperature per each gene (Table 1) for $40 \mathrm{~s}$, and $72{ }^{\circ} \mathrm{C}$ for $1 \mathrm{~min}$; and a final extension at $72{ }^{\circ} \mathrm{C}$ for $10 \mathrm{~min}$. The reference strains (E. coli ATCC 35218 and E. coli NCTC 13353) were used as the positive controls for the $b l a_{\mathrm{TEM}}$ and the $b l a_{\mathrm{CTX}-\mathrm{M}-1}$ group genes. For the $b l a_{\mathrm{OXA}-1}$ group gene, an $E$. coli isolate harboring the $b l a_{\mathrm{OXA}-1}$ gene that was kindly provided by the Central Laboratory of Faculty of Veterinary Medicine, Kafrelsheikh University, Egypt, was used as the control. The E. coli ATCC 25922 reference strain was used as a negative control for all PCR tests.

\section{Assessment of phenotypic antibiotic resistance}

According to the guidelines of the Clinical and Laboratory Standards Institute, the Kirby-Bauer disk diffusion technique was used to perform the antibiotic sensitivity tests [25]. Pure colonies were incubated in Mueller-Hinton broth (Oxoid, Hampshire, U.K.) at $37^{\circ} \mathrm{C}$ for 6 h. Each broth culture was diluted with sterile water until reaching a concentration of $0.5 \mathrm{McF}$ arland standard, and then $100 \mu \mathrm{L}$ of the dilution was spread on Mueller-Hinton agar (MHA, Oxoid, Hampshire, UK). Antibiotic discs (Oxoid, Hampshire, U.K.) were distributed onto the agar surface with a $30 \mathrm{~mm}$ distance from center to center. The following antibiotic discs were used: imipenem (IMP, $10 \mu \mathrm{g}$ ), meropenem (MEM, $10 \mu \mathrm{g}$ ), ampicillin (AMP, $10 \mu \mathrm{g})$, cephazolin $(30 \mu \mathrm{g})$, ceftazidime (CAZ, $30 \mu \mathrm{g})$, cefotaxime (CTX, $30 \mu \mathrm{g}$ ), nalidixic acid (NA, $30 \mu \mathrm{g})$, ciprofloxacin (CIP, $5 \mu \mathrm{g})$, streptomycin (S, $10 \mu \mathrm{g})$, kanamycin $(\mathrm{K}, 30 \mu \mathrm{g})$, gentamicin $(\mathrm{CN}, 10 \mu \mathrm{g})$, tetracycline (TE, $30 \mu \mathrm{g}$ ), chloramphenicol (C, $30 \mu \mathrm{g})$, and sulfamethoxazole/trimethoprim (SXT, $25 \mu \mathrm{g}$ ). All plates were incubated at $37^{\circ} \mathrm{C}$ for $18-24 \mathrm{~h}$, and the inhibition zone diameters were interpreted according to the CLSI guidelines (2016). Isolates that showed phenotypic resistance to CAZ or CTX were further tested for the production of ESBLs by the double-disk synergy test as previously described [26]. Briefly, each isolate was inoculated on the MHA plate, and then an amoxicillin/clavulanic acid disk (AMC, 20/10 $\mu \mathrm{g}$ ) was placed $25 \mathrm{~mm}$ from the CAZ $(30 \mu \mathrm{g})$ and CTX $(30 \mu \mathrm{g})$ disks. After incubation, the increase in the CAZ inhibition zone or CTX disks toward the AMC disk (keyhole shape) was recorded as positive ESBL production. Carbapenem-resistant isolates were tested for carbapenem production with the modified Hodge test [27]. In brief, the tenth dilution of the E. coli ATCC 25922 reference strain (0.5 McFarland-equivalent concentration) was inoculated on an MHA plate, and then a MEM disk $(10 \mu \mathrm{g})$ was placed in the center. Then, the isolates (three per plate) were streaked in a line from the MEM disk to the plate edge, and the plate was incubated overnight. Positive results were considered when E. coli ATCC 25922 increased around the test organism's growth streak within the disk inhibition zone (clover leaflike indentation).

For quality control, the following reference strains were used for each of antibiotic sensitivity, ESBL production, and carbapenemase production tests: E. coli ATCC BAA2469 (positive control for carbapenemase), E. coli NCTC 13353 (positive control for ESBL), and E. coli ATCC 25922 (negative control).

\section{Genotyping of STEC isolates using Enterobacterial repetitive intergenic consensus (ERIC)-PCR}

Genotyping with ERIC-PCR was conducted as previously described [28] using the following primers: ERIC1R: 5'ATGTAAGCTCCTGGGGATTCAC3' and ERIC2: 5'AAGTAAGTGACTGGGGTGAGCG3'. The reaction mixture was composed of $12.5 \mu \mathrm{L}$ of EmeraldAmp Max PCR Master Mix, $3 \mu \mathrm{L}$ of each primer ( $60 \mathrm{pmol}$ ), 5 $\mu \mathrm{L}$ of the DNA template (100 ng), and water to reach a total volume of $25 \mu \mathrm{L}$. The following cycling conditions were applied: 1 cycle at $95^{\circ} \mathrm{C}$ for $7 \mathrm{~min} ; 35$ cycles of $94{ }^{\circ} \mathrm{C}$ for $30 \mathrm{~s}, 52{ }^{\circ} \mathrm{C}$ for $1 \mathrm{~min}$, and $65^{\circ} \mathrm{C}$ for $5 \mathrm{~min}$; and a final extension at $65{ }^{\circ} \mathrm{C}$ for $15 \mathrm{~min}$. The PCR products were electrophoresed and photographed, as mentioned before. The ERIC-PCR band patterns were analyzed by GelJ software v.2.0 [29]. The comparison between ERIC-PCR profiles was conducted using the Dice coefficient, and a dendrogram was constructed using the unweighted pair group method with arithmetic mean. Simpson's discrimination index for ERIC genotyping was estimated as previously described [30].

\section{Statistical analysis}

The odds ratios and potential associations between phenotypic or genetic antibiotic resistance profiles and source (diarrheic cases versus food) of the STEC isolates were assessed using a univariate logistic regression model. The analysis was conducted using SPSS v19 (IBM, 
Armonk, NY, USA), and significance was recorded at $P \leq 0.05$.

\section{Results}

STEC were detected in 6.5\% (13/200) and 11\% (22/200) of foods and diarrheic cases, respectively. STEC prevalence rates of $6 \%(6 / 100), 7 \%$ (7/100), 10\% (10/100), and $12 \%(12 / 100)$ were reported in individual milk, beef, diarrheic human, and diarrheic cattle samples, respectively (Table 2). Six STEC serovars were detected; O26:H11 $(4.5 \%, 18 / 400)$ was the most prevalent serovar, followed by $\mathrm{O} 111: \mathrm{H} 2(1.5 \%, 6 / 400)$. The $\mathrm{O} 26: \mathrm{H} 11$ strains were detected in all sources, and the highest rates were found in diarrheic cattle $(9 \%, 9 / 100)$ and human $(4 \%, 4 / 100)$ samples. The O111:H2 strains were only detected in beef $(2 \%, 2 / 100)$ and human $(4 \%, 4 / 100)$ samples (Table 2$)$.

The $s t x 1$ and $s t x 2$ genes were detected in $82.9 \%(29 / 35)$ and $80 \%(28 / 35)$ STEC isolates, respectively. Most STEC isolates harbored both stx genes $(62.9 \%, 22 / 35)$; the remaining isolates carried either only the stx 2 gene (20\%, $7 / 35)$ or only the $s t x 1$ gene $(17.1 \%, 6 / 35)$. The genotype containing both stx genes predominated in all STEC sources: $69.2 \%(9 / 13)$ in foods, $58.3 \%(7 / 12)$ in cattle, and $60 \%(6 / 10)$ in humans. Furthermore, the highest rate of the stx2-only genotype was detected in clinical catthe isolates $(33.3 \%, 4 / 12)$. For the O26:H11 isolates, the both $s t x$ genes, the $s t x 2$ gene only, and the $s t x 1$ gene only genotypes were recorded in $61.1 \%(11 / 18), 33.3 \%(6 / 18)$, and $5.6 \%(1 / 18)$ of isolates, respectively (Fig. 1). Most O26:H11 isolates carrying the stx 2 gene were detected in diarrheic cattle isolates (4/6 isolates, Fig. 1). The $s t x 1$ gene only $(66.7 \%, 4 / 6)$ and both $s t x$ genes $(33.3 \%, 2 / 6)$ were the most prevalent genotypes for the O111:H2 serovar (Fig. 1). The serovar O157 was not detected in any of the examined samples.

CP STEC isolates that harbored at least one of the MBL genes were found in $1.8 \%$ of the examined samples, including $0.5 \%(1 / 200)$ of the food samples and $3 \%(6 / 200)$ of the diarrheic cases (Table 2). The $b l a_{\mathrm{VIM}}$ was the most prevalent MBL gene, and it was detected in $20 \%(7 / 35)$ of STEC isolates. One isolate carried the $b l a_{\mathrm{NDM}-1}$ gene with $b l a_{\mathrm{VIM}}(2.9 \%)$; however, the $b l a_{\mathrm{IMP}}$ gene was not detected in any isolates (Table 2). There was no significant association between the acquisition of CR genes and the STEC isolates' source; however, higher odds ratios were reported for diarrheic isolates (OR 6.2, $P=0.09$, 95\% CI 0.7-51.6).

The ESBL-producing STEC isolates were detected in $4.3 \%$ of the samples, including $1.5 \%$ of the food samples and $7 \%$ of the diarrheic cases (Table 2). Approximately half of the isolates carried ESBL genes $(48.6 \%, 17 / 35)$ : $42.9 \%(15 / 35)$ carried $b l a_{\text {TEM }}$ group genes, $28.6 \%(10 / 35)$ carried bla $a_{\mathrm{CTX}-\mathrm{M} 1}$ group genes, and $2.9 \%(1 / 35)$ carried $b l a_{\mathrm{OXA}-1}$ group genes (Table 3$)$. Half $(50 \%, 6 / 12)$ of the cattle clinical isolates carried both bla $a_{\mathrm{TEM}}$ and blaCTXM1 group genes, whereas only one human isolate carried both the $b l a_{\mathrm{TEM}}$ group and $b l a_{\mathrm{OXA}-1}$ group genes (Table 3). The ESBL-producing STEC isolates were 4.9 times more likely to be in clinical samples than in food samples $(P=0.006,95 \%$ CI 1.4-17.5).

Approximately two-thirds $(57.1 \%, 20 / 35)$ of the examined STEC isolates were phenotypically resistant to at least one antibiotic, and 18 (51.4\%) isolates were MDR to three or more classes of antibiotics, including eight cattle (22.9\%), seven human (20\%), and three food (8.6\%) isolates (Table 3). MDR STEC strains were 5.3 times more

Table 2 Frequency distribution of STEC serovars and drug resistance traits in samples collected from cattle and humans in this study

\begin{tabular}{|c|c|c|c|c|c|c|c|}
\hline \multirow[t]{2}{*}{ Serovar } & \multicolumn{3}{|c|}{ Foods of cattle origin } & \multicolumn{3}{|c|}{ Diarrheic cases } & \multirow{2}{*}{$\begin{array}{l}\text { Total } \\
\mathrm{N}=400\end{array}$} \\
\hline & $\begin{array}{l}\text { Milk } \\
\mathrm{N}=100\end{array}$ & $\begin{array}{l}\text { Beef } \\
N=100\end{array}$ & $\begin{array}{l}\text { Subtotal } \\
\mathrm{N}=200\end{array}$ & $\begin{array}{l}\text { Cattle } \\
\mathrm{N}=100\end{array}$ & $\begin{array}{l}\text { Humans } \\
\mathrm{N}=100\end{array}$ & $\begin{array}{l}\text { Subtotal } \\
\mathrm{N}=200\end{array}$ & \\
\hline O26:H11 & $3(3)$ & $2(2)$ & $5(2.5)$ & $9(9)$ & $4(4)$ & $13(6.5)$ & $18(4.5)$ \\
\hline $\mathrm{O} 111: \mathrm{H} 2$ & $0(0)$ & $2(2)$ & $2(1)$ & $0(0)$ & $4(4)$ & $4(2)$ & $6(1.5)$ \\
\hline $\mathrm{O} 91: \mathrm{H} 21$ & $2(2)$ & $0(0)$ & $2(1)$ & $1(1)$ & $1(1)$ & $2(1)$ & $4(1)$ \\
\hline O128:H2 & $0(0)$ & $3(3)$ & $3(1.5)$ & $1(1)$ & $0(0)$ & $1(0.5)$ & $4(1)$ \\
\hline O103:H2 & $1(1)$ & $0(0)$ & $1(0.5)$ & $0(0)$ & $1(1)$ & $1(0.5)$ & $2(0.5)$ \\
\hline O113:H4 & $0(0)$ & $0(0)$ & $0(0)$ & $1(1)$ & $0(0)$ & $1(0.5)$ & $1(0.3)$ \\
\hline Total STEC & $6(6)$ & $7(7)$ & $13(6.5)$ & $12(12)$ & $10(10)$ & $22(11)$ & $35(8.8)$ \\
\hline CR-STEC & $1(1)$ & $0(0)$ & $1(0.5)$ & $2(2)$ & $4(4)$ & $6(3)$ & $7(1.8)$ \\
\hline ESBL-STEC & $2(2)$ & $1(1)$ & $3(1.5)$ & $7(7)$ & $7(7)$ & $14(7)$ & $17(4.3)$ \\
\hline MDR-STEC & $2(2)$ & $1(1)$ & $3(1.5)$ & $8(8)$ & $7(7)$ & $15(7.5)$ & $18(4.5)$ \\
\hline
\end{tabular}

STEC: Shiga toxin-producing Escherichia coli; CR-STEC: carbapenemase-producing STEC; ESBL-STEC: extended-spectrum $\beta$-lactamase producing STEC; MDR-STEC: multidrug resistant STEC; brackets: percent: $\mathrm{N}$ : number of samples 

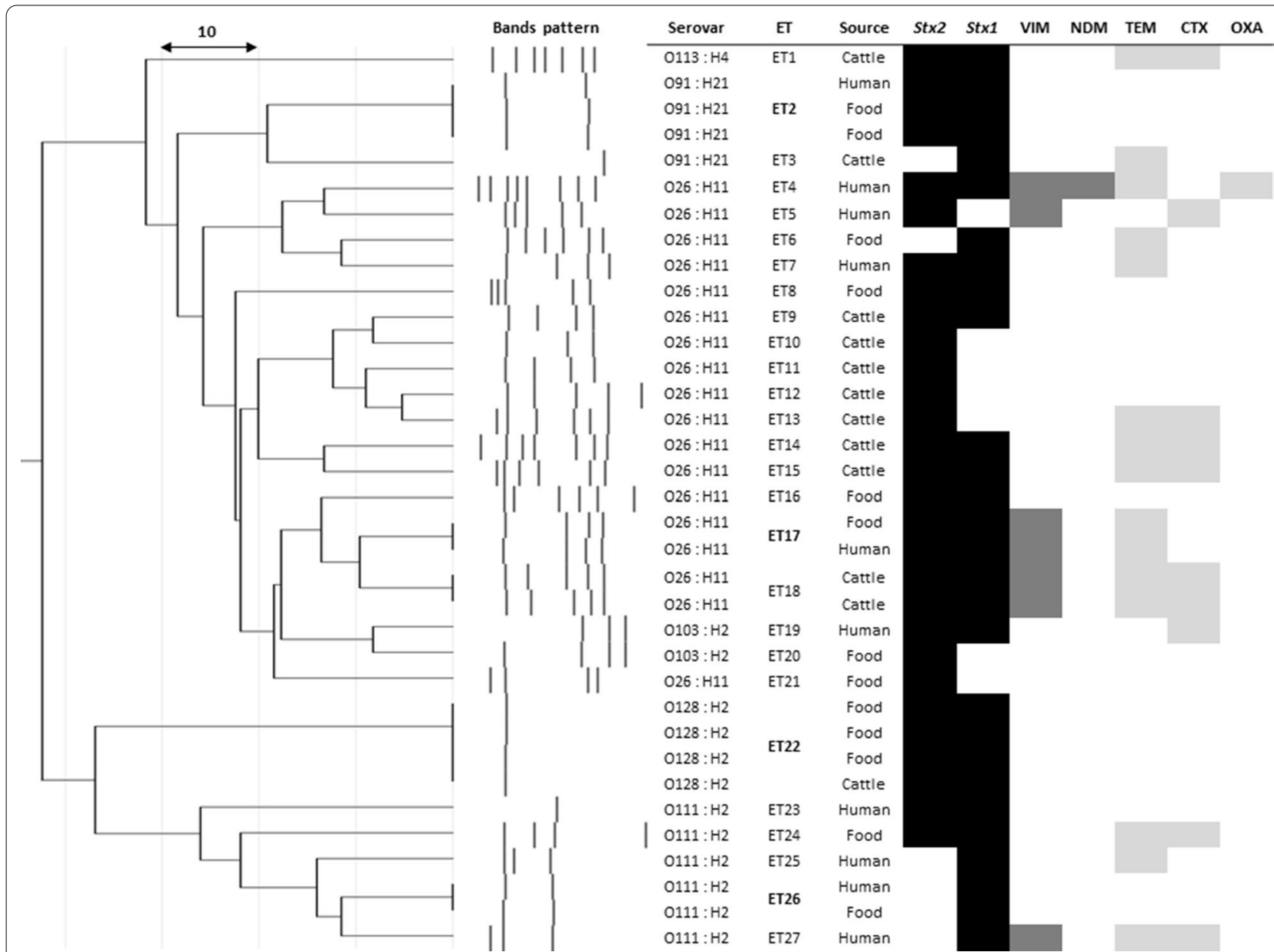

Fig. 1 Enterobacterial repetitive intergenic consensus (ERIC)-PCR genotyping and virulence-antibiotic resistance genes profiles of STEC isolates recovered from food of cattle origin, diarrheic cattle, and diarrheic humans in this study. ET: ERIC genotypes. Black shadow: virulence genes. Dark grey shadow: CR genes. Light grey shadow: ESBL genes. Bold ET: clusters of identical isolates

likely to be detected in diarrheic cases than in foods $(P=0.009,95 \%$ CI $1.5-18.7)$. Seven $(20 \%)$ isolates were resistant to the tested carbapenems (IMP and MEM). The highest resistant rates were reported for NA (51.4\%), AMP (48.6\%), and S (45.7\%), while the highest sensitivity rates were reported for $\mathrm{CN}$ (5.7\%), and CIP (11.4\%).

There was a concordance between the acquisition of carbapenemase- and $\beta$-lactamase-producing genes and the expression of phenotypic carbapenem and $\beta$-lactam resistance in all studied STEC isolates, respectively (Table 3). Interestingly, all carbapenem-resistant isolates were also resistant to $\beta$-lactams and harbored one or more other BL genes.

The ERIC-PCR based genotyping analysis of the STEC isolates from clinical cases (cattle and humans) and food products (milk and beef) is shown in Fig. 1. The ERIC band patterns ranged from 1 to 8 bands with a size range from 100 to $2000 \mathrm{bp}$. The dendrogram map classified the STEC isolates into 27 different ERIC genotypes (ETs) with a discrimination index of 0.979 . The isolates that belonged to the same serotype were clustered together (Fig. 1). The isolates belonging to serovars O26 (18 isolates displaying $16 \mathrm{ETs}$ ) and O111 showed high genetic diversity: 18 isolates displayed 16 ETs and 6 isolates displayed 5 ETs, respectively. By contrast, more relatedness was exhibited by the isolates of serovars O91 and O128: four isolates showed two ETs and four isolates showed one ET, respectively. Five ETs showed clusters of two to four identical isolates per ET (Fig. 1). These ET clusters either belonged to the same source (E18, diseased cattle) or were from different sources, such as diseased humans and foods (ET2, ET17, and ET26) and diseased cattle and foods (ET22). The isolates within the same ET shared identical virulence and antibiotic resistance genetic profiles (Fig. 1). 


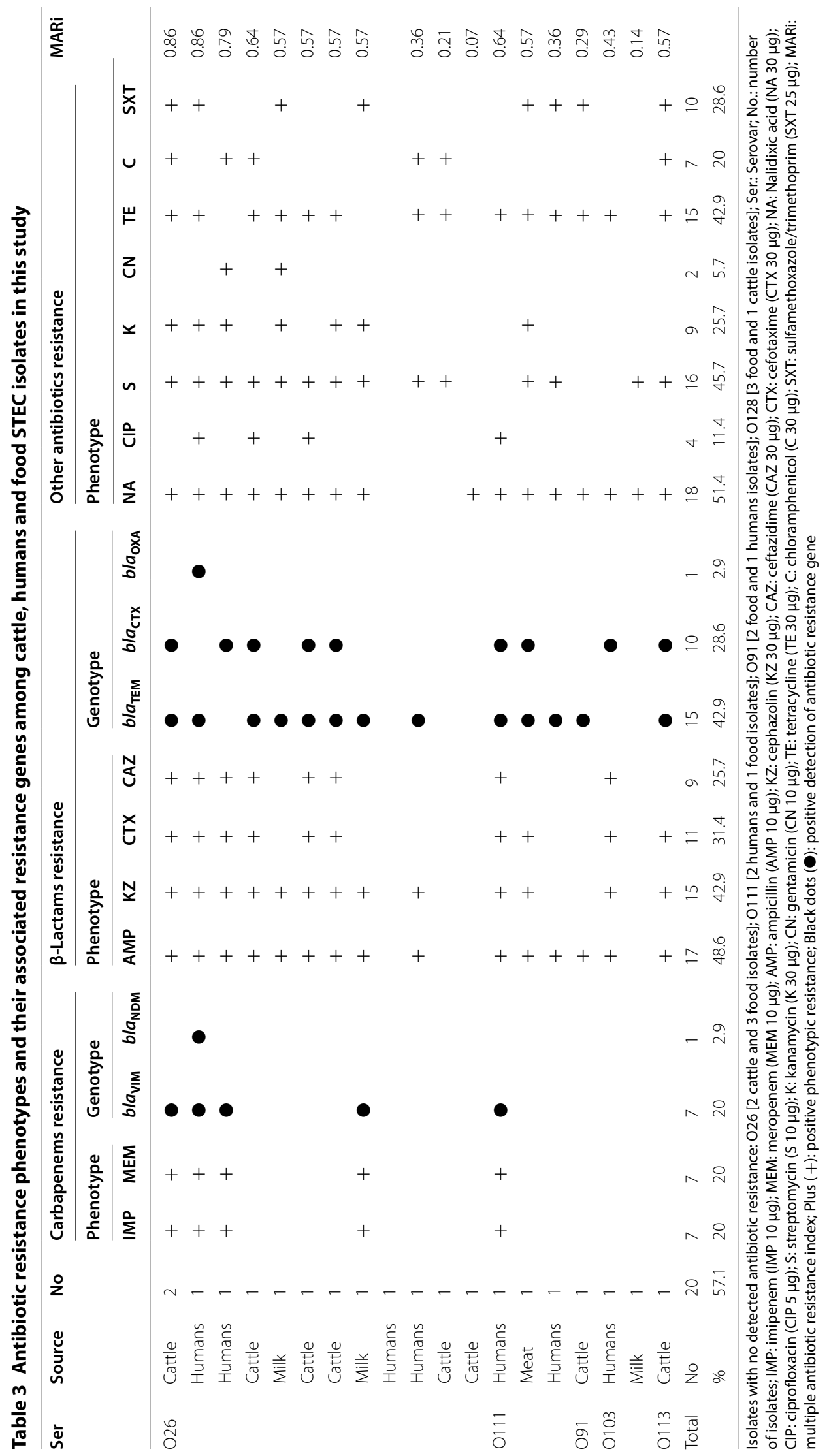




\section{Discussion}

This study investigated the prevalence and antibiotic resistance traits of STEC in the food of cattle origin (milk and meat) and diarrheic cases (cattle and humans). STEC was detected in $6.5 \%, 6 \%$, and $7 \%$ of all food, milk, and meat samples, respectively. These findings were higher than those in previous reports (1.9-4.1\%) in the USA [31] but lower than reports (10.7-29.7\%) from other countries [32-34]. STEC isolates were found in $12 \%$ of diarrheic cattle samples; higher rates (18.7-53.2\%) were reported from another location in Egypt [18] and elsewhere [31, $35]$. The prevalence rate in humans was $10 \%$, which was higher than that in other reports $(0.7-6.4 \%)$ in Africa [36], Europe [37], and Asia [35]. Most (60-69.2\%) of the food and human isolates displayed the genotype with both stx genes. Similarly, the same genotype predominated in human isolates from Canada [38] and Europe [37]. However, our findings differed from reports of food isolates [32, 34] and human isolates [36] found elsewhere. By contrast, the stx2-only genotype prevailed in diarrheic cattle isolates in this study, which agreed with reports from Canada [38], Argentina [10], and Egypt [18].

The serovars O26:H11 (4.5\%) and O111:H2 (1.5\%) were the most commonly detected STEC among the examined samples. Similarly, these serovars were detected in the food of cattle origin, live cattle, and diseased humans worldwide $[4,10,32,34,39]$. The O26:H11 serovar was reported to be the most frequently recorded non-O157 STEC responsible for human disease worldwide [10]. The most prevalent genotypes for the O26:H11 serovar were both $s t x$ genes $(61.1 \%)$ and $s t x 2$ only (33.3\%). The STEC O26 genotype with both $s t x$ genes has caused several human cases of bloody diarrhoea and HUS in the USA and Europe $[1,5,40]$. The STEC O26 genotype with stx2 only emerged in Europe in the mid-1990s and continues to be the most common non-O157 STEC etiology of HUS worldwide $[1,40]$. Interestingly, most of the STEC O26 isolates with the stx2 genotype were recovered from clinical cattle cases in this study, which highlights the potential zoonotic risk of this serovar. The O111:H2 serovar displayed two genotypes: stx 1 only $(66.7 \%)$ and both stx (33.3\%). STEC O111 strains (stx1 or both $s t x$ genes) were the leading cause of HUS cases in the USA from 1983 to 2002 [5]. The serovar O157 was not found in any of the examined samples. There is increasing global evidence over recent years of the increased prevalence of non-O157 STEC isolates among cattle and human samples $[4,10,39]$, which agrees with our findings.

Differences in STEC prevalence rates, genotypes, and serogroups between this study and previous studies may be attributed to differences in the geographical distribution of STEC strains, the sampling strategy, or the methodology.
Seven CP STEC isolates were found in $1.8 \%$ of our examined samples, including in one milk (1\%), two diarrheic cattle (2\%), and four diarrheic human (4\%) samples. These isolates carried the $b l a_{\mathrm{VIM}}$ gene, and one human isolate harbored both $b l a_{\mathrm{VIM}}$ and $b l a_{\mathrm{NDM}-1}$ genes; all of these isolates were also phenotypically resistant to IMP and MEM. Human CR-E. coli isolates harboring the $b l a_{\mathrm{VIM}}$ or $b l a_{\mathrm{NDM}}$ genes were identified in clinical isolates from Egypt [41] and other countries [15-17], which agreed with the study findings. Recent reports have shown the emergence of CR-E. coli isolates recovered from diarrheic cattle (carrying the $b l a_{\mathrm{VIM}}$ gene) and mastitic milk (carrying the $b l a_{\mathrm{NDM}}$ gene) in India. This agrees with the current study findings. By contrast, STEC isolates recovered from milk, and diarrheic cattle in previous studies from Egypt showed a complete sensitivity for carbapenems $[13,18]$. This is the first detection of CP STEC in milk and diarrheic cattle in Egypt. The emergence of CP STEC is an alarming threat to public health. MEM is recommended for treating STEC human cases to lower severe outcomes such as kidney damage [9]; thus, CP STEC may be life-threatening and has reduced therapeutic options. Unlike humans, carbapenems are not used in veterinary practice in Egypt and several other countries [14], so the acquisition of $\mathrm{CP}$ genes by catthe isolates may have originated from the environment, cross-species transmission of human $\mathrm{CP}$ isolates, and/or the transfer of $\mathrm{CP}$ genes via mobile genetic elements as plasmids from other CP-gut pathogens [14, 17]. Despite growing records of non-human sources of CR-E. coli worldwide, the role of cattle in the spread of CP STEC to humans or the environment is highly underestimated. This study provides additional evidence of the potential role of cattle and foods of cattle origin as CP STEC sources in the study area, which presents an emerging threat to public health.

Half of the STEC isolates carried ESBL-encoding genes (48.6\%); the respective detection rates of the examined $b l a_{\mathrm{TEM}}, b l a_{\mathrm{CTX}-\mathrm{M} 1}$ group, and $b l a_{\mathrm{OXA}-1}$ group genes were $42.9 \%, 28.6 \%$, and $2.9 \%$. The relative predominance of the $b l a_{\text {TEM }}$ gene in STEC isolates from foods, diseased cattle, and diseased humans has been recorded in several studies worldwide $[10,11,42]$. The $b l a_{\mathrm{CTX}-\mathrm{M} 1}$ and $b l a_{\mathrm{OXA}-1}$ genes were also recovered at variable rates from the same sources $[11,13,42]$. The $b l a_{\mathrm{TEM}}$ and $b l a_{\mathrm{OXA}-1}$ group genes encode variable narrow-spectrum BLs (NSBL) to ESBLs that confer resistance for penicillin and sometimes cephalosporins. In contrast, the $b l a_{\mathrm{CTX}-\mathrm{M} 1}$ group gene confers resistance to ESBLs such as third-generation cephalosporins [43]. The genetic profile of all ESBL-producing STEC isolates matched their phenotypic resistance. Interestingly, all CP STEC harbored one or more ESBL genes, which was in agreement with another study in 
Africa [15]. Additionally, ESBL-producing STEC isolates were five times more likely to be detected in clinical samples than in food samples $(P=0.006)$. These findings suggest the potential acquisition of ESBL genes by selective antibiotic pressure, particularly in clinical isolates (veterinary and humans), usually treated by cephalosporins.

The STEC isolates showed high phenotypic resistance rates to NA (51.4\%), AMP (48.6\%), S (45.7\%), and TE (42.9\%). Comparable findings were previously recorded in Egypt [13, 42] and elsewhere [32, 34]. The highest STEC isolates sensitivity rates were reported for CN (5.7\%) and CIP (11.4\%), which agrees with previous reports in Africa [13, 36]. By contrast, STEC isolates from Asia showed high resistance rates $(55.2-100 \%)$ to $\mathrm{CN}[32,34]$.

Approximately half $(51.4 \%, 18 / 35)$ of the STEC isolates showed the MDR phenotype, which agrees with other reports [13, 34, 42]. However, Kalule et al. [36] reported that none of the detected STEC isolates showed MDR in South Africa. Two-thirds $(61.1 \%, 11 / 18)$ of the MDR STEC were from diarrheic cattle and food samples. This finding denotes the emergence of MDR STEC from cattle and their food products in Egypt. In Egypt, antibiotics are misused in veterinary practices. Animals' owners can easily access antibiotics at local pharmaceutical vendors or private pharmacies without a prescription or supervision. This misuse of antibiotics may have contributed to our high recorded MDR STEC rates from animal sources and is a major zoonotic threat to residents in Egypt.

ERIC-PCR genotyping of the 22 clinical and 13 food isolates yielded 27 different ETs. This proved the high genetic diversity that exists between STEC isolates regardless of their source or serotype. Likewise, other studies on pathogenic E. coli isolates from clinical cases, and foods showed high genetic heterogeneity [15, 44, 45]. The ERIC band patterns ranged from 1 to 8 bands with a size range from 100 to $2000 \mathrm{bp}$, comparable with reports from China [45] and Ghana [15]. The STEC isolates of the same serotype were clustered together; however, there was a high genetic difference between strains of some serotypes such as $\mathrm{O} 26$ and O111. This agrees with other studies $[44,45]$ and may indicate the circulation of many different strains of these serotypes in the study area.

Five identical ETs were spotted from either the same source (diseased cattle) or different sources (diseased humans and food; diseased cattle and food); isolates with identical ETs carried matched virulence and antibiotic resistance profiles. The combinations of identical genetic ETs, virulence, and resistance profiles among some of the STEC isolates from the same or different sources highlight the potential inter or intra-species cross-transmission of these pathogens and/or their genes in the study region.

\section{Conclusions}

This work has confirmed a direct role of cattle as a source of CP STEC isolates. It has provided evidence of potential zoonotic transmission of these isolates to humans, representing an emerging public health threat in the study region. ESBL-producing STEC isolates were also recovered from diarrheic cattle and their food products. Taken together, we propose that extended surveillance of the cattle food chain and other clinical sources and mandatory veterinary supervision of antibiotic use for animals are urgently required to minimize the potential zoonotic risks of MDR STEC in Egypt.

\section{Acknowledgements}

The authors thank Taif University Researchers Supporting Project number (TURSP-2020/138) for support this study, Taif University, Taif, Saudi Arabia.

\section{Authors' contributions}

Conceptualization: WE; methodology: WE, SS, EMA, RE, AT and RNZ; investigation: WE, SS, AT, RE and RNZ; Data analysis: WE, RNZ, MF, MS and HE; writing original draft: WE; writing-review and editing:WE, EMA, RE, AT, MF, MS and RNZ, Supervision: All authors read and approved the final manuscript.

\section{Funding}

Taif University Researchers Supporting Project number (TURSP-2020/138) is supported this study, Taif University, Taif, Saudi Arabia.

\section{Availability of data and materials}

The datasets used in the present study are accessible on reasonable request from the corresponding author.

\section{Ethics approval and consent to participate}

All study procedures were approved ethically by the Hygiene and Preventive Medicine research committee, Faculty of Veterinary Medicine, Kafrelsheikh University, Egypt. The health facilities' medical staff collected all human samples after describing the participating patients' research details. Additionally, written consent was obtained before sample collection.

\section{Consent for publication}

Not applicable.

\section{Competing interests}

The authors declare that they have no competing interests.

\begin{abstract}
Author details
${ }^{1}$ Department of Hygiene and Preventive Medicine (Zoonoses), Faculty of Veterinary Medicine, Kafrelsheikh University, Kafrelsheikh, Egypt. ${ }^{2}$ Department of Animal Medicine, Faculty of Veterinary Medicine, Kafrelsheikh University, Kafrelsheikh, Egypt. ${ }^{3}$ Department of Biotechnology, College of Science, Taif University, P.O. Box 11099, Taif 21944, Saudi Arabia. ${ }^{4}$ Food Research Institute, Agriculture Research Center, Giza, Egypt. ${ }^{5}$ Department of Bacteriology, Mycology and Immunology, Faculty of Veterinary Medicine, Kafrelsheikh University, Kafrelsheikh, Egypt. ${ }^{6}$ Department of Biology, College of Science, Taibah University, Madina, Saudi Arabia. ${ }^{7}$ Department of Microbiology and Immunology, Faculty of Medicine, Tanta University, Tanta, Egypt. ${ }^{8}$ Department of Poultry and Rabbit Diseases, Faculty of Veterinary Medicine, Kafrelsheikh University, Kafrelsheikh, Egypt. ${ }^{9}$ Department of Physiology, Faculty of Veterinary Medicine, Kafrelsheikh University, Kafrelsheikh, Egypt. ${ }^{10}$ Department of Bacteriology, Mycology, and Immunology, Faculty of Veterinary Medicine, University
\end{abstract} of Sadat City, Sadat, Egypt.

Received: 3 October 2020 Accepted: 28 January 2021

Published online: 05 February 2021 


\section{References}

1. Organization WH. Shiga toxin-producing Escherichia coli (STEC) and food: attribution characterization and monitoring. Geneva: World Health Organization; 2019

2. Mughini-Gras L, Van Pelt W, Van der Voort M, Heck M, Friesema I, Franz E. Attribution of human infections with Shiga toxin-producing Escherichia coli (STEC) to livestock sources and identification of source-specific risk factors, The Netherlands (2010-2014). Zoonoses Public Health. 2018;65(1):e8-22.

3. Martens SL, Klein S, Barnes RA, TrejoSanchez P, Roth CC, Ibey BL. 600-ns pulsed electric fields affect inactivation and antibiotic susceptibilities of Escherichia coli and Lactobacillus acidophilus. AMB Express. 2020;10(1):1-11.

4. Jajarmi M, Fooladi AAl, Badouei MA, Ahmadi A. Virulence genes, Shiga toxin subtypes, major O-serogroups, and phylogenetic background of Shiga toxin-producing Escherichia coli strains isolated from cattle in Iran. Microb Pathog. 2017;109:274-9.

5. Brooks JT, Sowers EG, Wells JG, Greene KD, Griffin PM, Hoekstra RM, et al. Non-O157 Shiga toxin-producing Escherichia coli infections in the United States, 1983-2002. J Infect Dis. 2005;192(8):1422-9.

6. Bielaszewska M, Mellmann A, Bletz S, Zhang W, Köck R, Kossow A, et al Enterohemorrhagic Escherichia coli O26: $\mathrm{H} 11 / \mathrm{H}-$ : a new virulent clone emerges in Europe. Clin Infect Dis. 2013;56(10):1373-81.

7. Hornitzky MA, Mercieca K, Bettelheim KA, Djordjevic SP. Bovine feces from animals with gastrointestinal infections are a source of serologically diverse atypical enteropathogenic Escherichia coli and Shiga toxinproducing E. coli strains that commonly possess intimin. Appl Environ Microbiol. 2005;71(7):3405-12

8. Majowicz SE, Scallan E, Jones-Bitton A, Sargeant JM, Stapleton J, Angulo FJ, et al. Global incidence of human Shiga toxin-producing Escherichia coli infections and deaths: a systematic review and knowledge synthesis. Foodborne Pathog Dis. 2014;11(6):447-55.

9. Mir RA, Kudva IT. Antibiotic-resistant Shiga toxin-producing Escherichia coli: an overview of prevalence and intervention strategies. Zoonoses Public Health. 2019;66(1):1-13.

10. Krüger A, Lucchesi P, Sanso AM, Etcheverría Al, Bustamante AV, Burgán J, et al. Genetic characterization of Shiga toxin-producing Escherichia coli O26: H11 strains isolated from animal, food, and clinical samples. Front Cell Infect Microbiol. 2015;5:74.

11. Day M, Doumith $M$, Jenkins C, Dallman TJ, Hopkins KL, Elson R, et al. Antimicrobial resistance in Shiga toxin-producing Escherichia coli serogroups $\mathrm{O} 157$ and $\mathrm{O} 26$ isolated from human cases of diarrhoeal disease in England, 2015. J Antimicrob Chemother. 2016;72(1):145-52.

12. Nagel S, Spüler M. World's fastest brain-computer interface: combining EEG2Code with deep learning. PLOS ONE. 2019;14(9):e0221909.

13. Elafify M, Khalifa HO, Al-Ashmawy M, Elsherbini M, El Latif AA, Okanda T, et al. Prevalence and antimicrobial resistance of Shiga toxin-producing Escherichia coli in milk and dairy products in Egypt. J Environ Sci Health Part B. 2020:55(3):265-72.

14. Köck R, Daniels-Haardt I, Becker K, Mellmann A, Friedrich AW, Mevius D, et al. Carbapenem-resistant Enterobacteriaceae in wildlife, food-produc ing, and companion animals: a systematic review. Clin Microbiol Infect. 2018;24(12):1241-50.

15. Codjoe FS, Donkor ES. Carbapenem resistance: a review. Med Sci. 2018;6(1):1

16. Ghatak S, Singha A, Sen A, Guha C, Ahuja A, Bhattacharjee U, et al. Detection of New Delhi metallo-beta-lactamase and extended-spectrum betalactamase genes in Escherichia coli isolated from mastitic milk samples. Transboundary Emerg Dis. 2013;60(5):385-9.

17. Murugan MS, Sinha D, Kumar OV, Yadav AK, Pruthvishree B, Vadhana P, et al. Epidemiology of carbapenem-resistant Escherichia coli and first report of blaVIM carbapenemases gene in calves from India. Epidemiol. Infect. 2019;147

18. Sobhy NM, Yousef SG, Aboubakr HA, Nisar M, Nagaraja KV, Mor SK, et al. Virulence factors and antibiograms of Escherichia coli isolated from diarrheic calves of Egyptian cattle and water buffaloes. PLoS ONE. 2020;15(5):e0232890.

19. Fagan PK, Hornitzky MA, Bettelheim KA, Djordjevic SP. Detection of Shiga-like toxin (stx1 andstx2), intimin (eaeA), and enterohemorrhagic Escherichia coli (EHEC) hemolysin (EHEC hlyA) genes in animal feces by multiplex PCR. Appl Environ Microbiol. 1999;65(2):868-72.
20. Gannon V, King RK, Kim JY, Thomas E. Rapid and sensitive method for detection of Shiga-like toxin-producing Escherichia coli in ground beef using the polymerase chain reaction. Appl Environ Microbiol. 1992;58(12):3809-15.

21. Tsakris A, Pournaras S, Woodford N, Palepou M-FI, Babini GS, Douboyas J, et al. Outbreak of infections caused by Pseudomonas aeruginosa producing VIM-1 carbapenemase in Greece. J Clin Microbiol. 2000;38(3):1290-2.

22. Ruiz M, Marti S, Fernandez-Cuenca F, Pascual A, Vila J. High prevalence of carbapenem-hydrolysing oxacillinases in epidemiologically related and unrelated Acinetobacter baumannii clinical isolates in Spain. Clin Microbiol Infect. 2007;13(12):1192-8.

23. Caporaso JG, Kuczynski J, Stombaugh J, Bittinger K, Bushman FD, Costello EK, et al. QIIME allows analysis of high-throughput community sequencing data. Nat Methods. 2010;7(5):335-6.

24. Ogutu JO, Zhang Q, Huang Y, Yan H, Su L, Gao B, et al. Development of a multiplex PCR system and its application in detection of bla SHV, bla TEM, bla CTX-M-1, bla CTX-M-9 and bla OXA-1 group genes in clinical Klebsiella pneumoniae and Escherichia coli strains. J Antibiot. 2015;68(12):725-33.

25. Wayne A. Clinical and Laboratory Standards Institute; CLSI. 2011. Performance standards for antimicrobial susceptibility testing. 20th Informational Supplement. CLSI document.

26. Drieux L, Brossier F, SougakoffW, Jarlier V. Phenotypic detection of extended-spectrum $\beta$-lactamase production in Enterobacteriaceae: review and bench guide. Clin Microbiol Infect. 2008;14:90-103.

27. Amjad A, Mirza IA, Abbasi S, Farwa U, Malik N, Zia F. Modified Hodge test: a simple and effective test for detection of carbapenemase production. Iran J Microbiol. 2011;3(4):189.

28. Versalovic J, Koeuth T, Lupski R. Distribution of repetitive DNA sequences in eubacteria and application to finerpriting of bacterial enomes. Nucleic Acids Res. 1991;19(24):6823-31.

29. Heras J, Domínguez C, Mata E, Pascual V, Lozano C, Torres C, et al. GelJ_-a tool for analyzing DNA fingerprint gel images. BMC Bioinform. 2015;16(1):1-8.

30. Hunter PR, Gaston MA. Numerical index of the discriminatory ability of typing systems: an application of Simpson's index of diversity. J Clin Microbiol. 1988:26(11):2465-6.

31. Lambertini E, Karns JS, Van Kessel JAS, Cao H, Schukken YH, Wolfgang DR, et al. Dynamics of Escherichia coli virulence factors in dairy herds and farm environments in a longitudinal study in the United States. Appl Environ Microbiol. 2015:81(13):4477-88.

32. Momtaz H, Dehkordi FS, Rahimi E, Ezadi H, Arab R. Incidence of Shiga toxin-producing Escherichia coli serogroups in ruminant's meat. Meat Sci. 2013;95(2):381-8

33. Samadpour M, Kubler M, Buck F, Depavia G, Mazengia E, Stewart J, et al. Prevalence of Shiga toxin-producing Escherichia coli in ground beef and cattle feces from King County. Wash J Food Prot. 2002;65(8):1322-5.

34. Ranjbar R, Dehkordi FS, Shahreza MHS, Rahimi E. Prevalence, identification of virulence factors, O-serogroups and antibiotic resistance properties of Shiga-toxin producing Escherichia coli strains isolated from raw milk and traditional dairy products. Antimicrob Resist Infect Control. 2018;7(1):53.

35. Badouei MA, Jajarmi M, Mirsalehian A. Virulence profiling and genetic relatedness of Shiga toxin-producing Escherichia coli isolated from humans and ruminants. Comp Immunol Microbiol Infect Dis. 2015;38:15-20.

36. Kalule JB, Keddy KH, Nicol MP. Characterisation of STEC and other diarrheic E. coli isolated on $\mathrm{CHROMagar}{ }^{\mathrm{TM}}$ STEC at a tertiary referral hospital, Cape Town. BMC Microbiol. 2018;18(1):55.

37. Falup-Pecurariu O, Lixandru RI, Cojocaru E, Csutak K, Monescu V, Muhsen $\mathrm{K}$, et al. Shiga toxin producing Escherichia coli-associated diarrhea and hemolytic uremic syndrome in young children in Romania. Gut Pathog. 2019;11(1):46.

38. Chandran A, Mazumder A. Prevalence of diarrhea-associated virulence genes and genetic diversity in Escherichia coli isolates from fecal material of various animal hosts. Appl Environ Microbiol. 2013;79(23):7371-80.

39. Hussein $\mathrm{H}$, Bollinger $\mathrm{L}$. Prevalence of Shiga toxin-producing Escherichia coli in beef. Meat Sci. 2005;71(4):676-89.

40. Bialaszewski D. Student attitudes regarding Ebooks; a survey with cost savings implications. J Syst Cybern Inform. 2013;11(5):76-9.

41. El-Kholy AA, Girgis SA, Shetta MA, Abdel-Hamid DH, Elmanakhly AR. Molecular characterization of multidrug-resistant Gram-negative 
pathogens in three tertiary hospitals in Cairo, Egypt. Eur J Clin Microbiol Infect Dis. 2020:1-6.

42. Ahmed AM, Shimamoto T. Molecular analysis of multidrug resistance in Shiga toxin-producing Escherichia coli $\mathrm{O} 157: \mathrm{H} 7$ isolated from meat and dairy products. Int J Food Microbiol. 2015;193:68-73.

43. Kim Y-R, Kim S-I, Lee J-Y, Park Y-J, Lee K-Y, Kang M-W. Nosocomial transmission of CTX-M-15 and OXA-30 $\beta$-lactamase-producing Escherichia coli in a neurosurgical intensive care unit. Ann Clin Lab Sci. 2005;35(3):297-301.

44. Prabhu V, Isloor S, Balu M, Suryanarayana V, Rathnamma D. Genotyping by ERIC-PCR of Escherichia coli isolated from bovine mastitis cases. 2010.
45. Zhang $S, W u$ Q, Zhang J, Zhu X. Occurrence and characterization of enteropathogenic Escherichia coli (EPEC) in retail ready-to-eat foods in China. Foodborne Pathog Dis. 2016;13(1):49-55.

\section{Publisher's Note}

Springer Nature remains neutral with regard to jurisdictional claims in published maps and institutional affiliations.
Ready to submit your research? Choose BMC and benefit from:

- fast, convenient online submission

- thorough peer review by experienced researchers in your field

- rapid publication on acceptance

- support for research data, including large and complex data types

- gold Open Access which fosters wider collaboration and increased citations

- maximum visibility for your research: over 100M website views per year

At BMC, research is always in progress.

Learn more biomedcentral.com/submissions 